\title{
OSSIAN-ILLUSTRATIONER I DANMARK
}

$\mathrm{AF}$

\section{Charlotte Christensen}

$\mathrm{D}$ en romantiske understrøm i det $\mathrm{i}$ 8. århundredes kultur skabte en fornyet interesse for digterværker med et bevæget folelsesindhold og af sproglig majestæt som Iliaden og Odysseen, Shakespeares værker og Bibelen. I i 760 'erne føjedes til disse Ossians Digte, af dunkel og omdisputeret oprindelse, der straks vakte opsigt over hele Europa. Emnekredsen var ganske ny: krigerdåd og kærlighed i den nordiske hedenold, i kommentarerne nærmere bestemt som den romerske kejser Caracallas tid. På trods af deres angivelige ælde fremstod de pludseligt fra oldtiden fremdukkede sange $\mathrm{i}$ en besnærende moderne form, og for nordiske læsere ejede de desuden den tiltrækning at skuepladsen var de sjældent besungne skotske heder og bjerge. Med al tænkelig patos fremmanedes billedet af tågelandskabet og de vældige skandinaviske skove, og denne naturlyrik væves ind i personskildringen derved at de stærke helte og hvidbarmede kvinder ofte karakteriseres ved metaforer, hentet fra den nordiske vilde natur. Når den blinde skjald - eller 'barde' - omsust af forfedrenes ånder besang deres heltegerninger, var tonen oftest dybt melankolsk, og den linje i digtene, der oftest blev påkaldt i den følsomme tid, var: "There is a joy in grief, when peace dwells in the breast of the sad ". ${ }^{1}$ )

Fra første fard herskede der mystik om digtenes proveniens. Den tidligste samling blev udgivet anonymt i Edinburgh i 1760 under titlen: „Fragments of Ancient Poetry Collected in the Highlands of Scotland, and translated from the Galic or Erse Language". Det kom dog snart frem, at „oversætteren" var den unge højlandsskotte James Macpherson, og til hans egen forundring vakte det lille bind fragmenter furore i den litterære verden. En af årsagerne til den store opmærksomhed var at den skotske nationalfolelse ved denne tid var i hastig vakst, hvorfor den ganske 
uventede fremkomst af en hjemlig digtskat fra det 3. ârhundrede hilstes med jubel og forventningen om at fragmenterne snart måtte samles til et større nationalt epos.

Dette håb om at tilvejebringe et skotsk sidestykke til de homeriske digte imødekom Macpherson til dels ved året efter at udgive „Fingal, an Ancient Epic Poem, in Six Books, together with several other Poems, Composed by Ossian, the Son of Fingal. Translated from the Galic Language, by James Macpherson" der i ${ }_{1} 763$ fulgtes af „Temora, an Ancient Epic Poem . ...". Alle digtene samledes i i 765 under titlen „The Works of Ossian" der indeholdt en af handling om deres autenticitet ved Hugh Blair. ${ }^{2}$ )

Allerede da de forste fragmenter blev udgivet indledtes striden om de ossianske sanges ægthed der med megen voldsomhed fortsattes de næste 5o år. Englænderne var de forste til at forkaste digtene og antage at de var sammenskrevne af Macpherson alle til hobe, hvorimod læserne i Tyskland og Skandinavien lange godtog angivelsen at Ossian og andre af fortidens skjalde havde digtet sangene, som barderne i de skotske højlande siden havde holdt $i$ live. Sagens rette sammenhæng synes at være den at Macpherson fik indsamlet viser af højst forskellig alder og oprindelse der på hans tid endnu blev foredraget $\mathrm{i}$ folket, men at han i sin oversættelse fra gælisk behandlede stoffet meget frit og selv tilskrev mange passager, idet han under indflydelse af sin samtids litterære smag omdannede sangene. Da hans kendskab til gælisk ydermere var ret beskedent kunne han forholde sig des friere til det overleverede materiale.

Den almindelige læser havde ikke store muligheder for at danne sig en begrundet mening om varkernes autenticitet ved deres fremkomst, da grundlaget for sammenligning var yderst ringe. Hverken Beowulf, Kalevala, Nibelungenlied eller Rolandskvadet var udgivne, og de islandske sagaer var i i 76o knap nok kendt uden for de lardes kreds, så det var vanskeligt at afveje hvor gamle Ossian-digtene kunne være og hvor frit Macpherson måtte antages at have forholdt sig til det oprindelige forlæg.

I modsxtning til den engelske skepticisme var den kontinentale reaktion på udgivelsen som oftest glødende enthousiasme, især i den germanske kulturkreds. Klopstocks og Gerstenbergs digtning kom meget tidligt under indflydelse af de ossianske sange, og Herder oversatte begejstret dele deraf, ja lod dem oplæse ved sit dødsleje. Goethe bidrog mere end nogen anden digter til at styrke deres popularitet ved at indlægge de vemodige "Selmas sange“ og dele af digtet „Berrathon“ i „Die Leiden des jungen Werthers" hvor mange lasere kom til at stifte det første bekendtskab med Ossian. Werther oversætter digtene som en hyldest til 


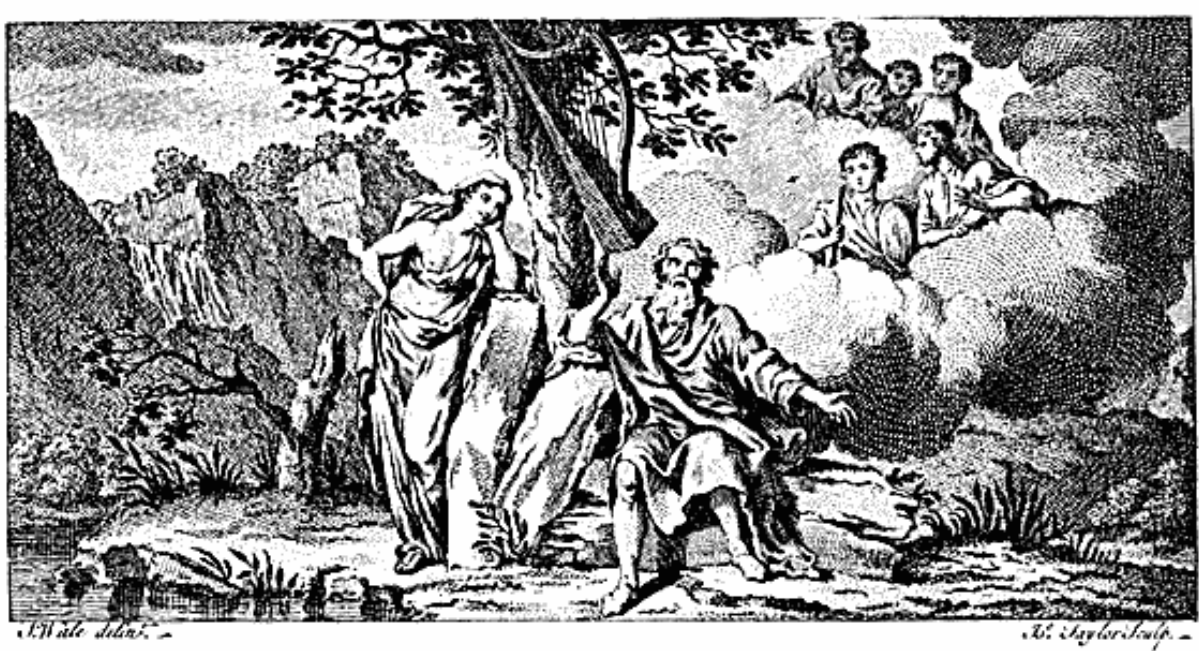

Titelvignet, udfort af Isaac Taylor til forsteudgaven af Fingal, London 1761 . Originalens storrelse $7 \times 13 \mathrm{~cm}$.

sin elskede Lotte og begynder at recitere dem for hende under deres sidste bevægede møde, indtil tårer og passion gør et videre foredrag umuligt. ${ }^{3}$ )

Begejstringen nåede også hurtigt Danmark, og den følsomme læser kunne gennemleve det skotske tågelandskabs dramatik og genfinde de bevægede naturoptrin i hjemlige omgivelser. Således skriver den unge og sværmeriske Zoëga fra Kerteminde klokken tre om natten en novemberdag i ${ }_{77}^{8}$ til sin ven: „Ich starre vor Kälte, wie Elred im Walde als er Moina's Hütte suchte bey Mondenschein . . . stürmt und braust draussen, und höre ich die Wogen einherstürzen, ich möchte noch eine Scene in King Lear lesen. Der arme Tom ist kalt" ".4)

En lige så stor betagelse følte den 13 -årige Friederike Brun ved Ossianlæsningen: „Ich lebte und webte in seiner dunkelklaren Geisterwelt, und verlor mich in den hohen reinen Gefühlen, welche er atmet ".5)

En anden belæst dame, grevinde Sybille Reventlow, var anderledes robust. Hun skriver til sin korrespondent grevinde Luise Stolberg om de mere gruelige dele af de ossianske digte der gjorde indtryk på hende: "des figures gigantesques faisant des pas d'un rocher à l'autre et qui en coupant têtes et bras goutent un plaisir bien doux ". ${ }^{6}$ )

Melankolsk natur og genfærd, ædle og blide folelser, kamptummel og heltegerninger beskrevet i en rytmisk skridende, naturlig og vardig prosa det kan ikke undre at unge digtere blev grebet af denne læsning. Den første danske poet der blev inderligt optaget af Ossian-digtene, var 
Johannes Ewald hvis interesse styrkedes af Klopstock, for hvem de var en åbenbaring af den germanske oldtid. Det var $\mathrm{i}$ de første år ikke blot for de digteriske kvaliteter man læste Ossian, men også fordi de betragtedes som historiske kildeskrifter om den fjerne nordiske fortid. Antikvarerne granskede deres vidnesbyrd, og Klopstock udkastede i 1780 en vidtløftig plan efter hvilken Ewald, ,skulde i Selskab af en Componist have reyst til Nord-Skotland, Ørkenøerne, Island, og Nordlandene, og der af Indbyggernes Munde have samlet alle de gamle Sange, som Macpherson enten havde levnet eller slet ikke søgt". Med dette mål for øje begyndte Ewald at studere de ,gamle nordiske og blant disse det celtiske Sprog", men da Bernstorff faldt og Klopstock forlod Danmark, blev denne sære plan til intet. ${ }^{7}$ )

Om den næring Ewald fandt for sin egen digtning i Ossian-sangene skriver han i fortalen til de Samtlige Skrifter, I, I 780 , p. xxxI: "Strax efter denne Tid, traf noget ind, som gav min Smag en ny Vending: Wielands Oversættelse af Shakespear og den prosaiske af Machpersons (sic) Ossian faldt mig i Hænderne, og saa ufuldkomne som disse ere, opvakte de dog, jeg vil ikke sige, en Lyst, men en Trang hos mig til at lære Engelsk. Jeg lærte det, og hvilket bundløst Væld af Digterrigdom aabnede sig nu for mig... Det forste Stykke af Betydenhed, som jeg skrev efter denne Tid, var Rolf Krage. Enhver opmerksom Læser vil finde min forandrede Smag heri". Ikke blot i Rolf Krage, men overalt i Ewalds vark findes efterklange af Ossian - i „Rungsteds Lyksaligheder“ såvel som i Kongesangen eller beskrivelsen af Arendses skønhed i „Levnet og Meninger ". ${ }^{8}$ )

Ewald havde forberedt sin ossianske rejse ved studier i historikeren P.F.Suhms omfattende bibliotek, medens Suhm selv undersogte Ossiandigtene for vidnesbyrd om skandinaviske forhold i sit værk „Om Odin og den hedniske Gudelære" fra i 77ı. Nogle af bøgerne foregår i Skandinavien, medens andre indeholder beretninger om nordboernes overfald på de britiske øer som i „Fingal“, hvor Swaran, kongen af Sora, hjemsøger Irland. Suhm tyder lokaliteten „Inisthona“ som Sjælland, og Frederik Münter sluttede sig til denne formodning i en længere afhandling om "Lejre i Sjelland“ i „Det skandinaviske Litteraturselskabs Skrifter" for I 805, II - i modstrid med Gerstenbergs antagelse, at dette navn angiver øen Sylt. Suhm interesserede sig især for afsnittene om den vældige gud Lora der angives at være identisk med skandinavernes Odin, og hans bog kom til at få stor betydning for de danske digteres behandling af oldnordiske emner ${ }^{9}$ ). Med Suhms bogsamling kom iøvrigt mange værker om Ossian-kontroverserne til Det kongelige Bibliotek. 
Det var kun forholdsvis få danske i det I8. århundrede der som Suhm beherskede engelsk, da dette sprog var lidet gangbart, og ikke alle læsere havde som Ewald energi til at tilegne sig det blot for at læse Ossian. Det syntes derfor påkrævet at tilvejebringe en dansk oversættelse, og i „Nyeste Kjøbenhavnske Efterretninger om lærde Sager for Aar 1789“, p. 544, indrykkede Chr. Olufsen og H.W. Riber en "Subskriptions-Plan“" med de højtidelige indledningsord: „Hele Europa kjender og beundrer Ossians Værker. De beundres ikke blot som ærværdige Levninger af den fjerneste Oldtid, men tillige som de sandeste Digte, Verden endnu har seet. Man finder hos denne Celtiske Barde fra det tredie Aarhundrede Digtekunsten $\mathrm{i}$ al sin Originalitet. Ikke blot $\mathrm{i}$ hans større Digte Fingal og Temora, men i hans øvrige mindre Digte møder man Plan og Anordning; sikkre og bestemte Charakteertegninger; rørende Situationer og Følelsernes meest treffende Udtryk ". ${ }^{10}$ )

Trods de henforte ord i denne subskriptionsindbydelse lykkedes det ikke at hverve en tilstrækkelig talrig læserkreds til at kunne udgive den påtænkte oversættelse. Annoncen fremhæver ellers nøje de elementer der drog præromantikens læsere til digtene: „Ossian var selv baade Helt og Digter. Han besynger de Optrin, han selv saae. Overalt fremskinner hans varme Hjerte, hans Følelse for mandigt Mod og høje Dyder, og hans til sødt Sværmerie ganske stemte Sjel. Man seer Krigeren, men altid den menneskelige, blide Kriger, der vel i al muelig Begeistring besynger Kampen, men dog gjerne stemmer sin Harpe til melancholsk Klage paa sin faldne Vens Gravhøi, eller lader den elskende Pige udgyde sin Veemodighed ved Heltens Liig." ")

Den første nogenlunde fuldstændige danske oversættelse blev i stedet „Ossians Digte oversatte af det Engelske ved Andreas Christian Alstrup“, I 790-I 79I, der af anmelderen i "Kiøbenhavnske lærde Efterretninger“ fik skudsmålet: „Nærværende Oversættelse kan ikke kaldes slet, men er ogsaa langtfra at være god ", hvilket er en ganske rimelig karakteristik. ${ }^{11}$ ) Tidsskriftet Iris gav Alstrups gendigtning en blidere medfart: „naar man ikke vil see paa Smaating, er denne danske Ossian ret god, og brugbar for dem, der ville kiende denne Digters Skiønheder og sammenligne ham med andre store Sangere. " ${ }^{12}$ )

I de danske tidsskrifter forekom tid efter anden Ossian-oversættelser af enkelte brudstykker hvoraf den mest bemærkelsesværdige er Malthe Conrad Bruuns glimrende gendigtning af et af de lyriske højdepunkter, „Karthon", der indeholder den meget beundrede og ofte efterlignede Ode til Solen. ${ }^{13}$ ) Omtrent fra samme tid skriver sig Oehlenschlägers ungdomsbetagelse af Ossian-sangene hvis mål han anlægger i det højspændte 
drama „Erik og Roller“, ligesom han i „Guldhornene“ og andre dele af „Digte 1803 “ oser af denne kilde.

Oehlenschlägers interesse for "vore Forfædres Naboer, Biergskotterne“, som han kaldte dem, var antagelig i høj grad næret af „Die Leiden des jungen Werthers", og fascinationen blev kun kortvarig. Den nordiske mytologi kom snart til at overskygge hans interesse for hojlandets sange, og i „Digtekunsten" fra 1849 skoser han endda i digtet "Monotonien" deres ensformighed. Da F.L.Mynster samme år ved subskription søgte at finde en læserkreds for sin påtænkte versificerede Ossian-gendigtning skrev han til Oehlenschläger for at interessere ham derfor, men fik kun et venligt og ganske uforpligtende svar som han tydede således, at Oehlenschlägers kendskab til Ossian var begrænset til enkelte dele - og særlig dem, Goethe havde oversat. ${ }^{14}$ )

For Steen Steensen Blicher blev Ossian-læsningen langt mere betydningsfuld end for Oehlenschläger. Det var Chr. Olufsen, hvis oversættelse af de skotske sange ikke var blevet realiseret, der henledte Blichers opmærksomhed på deres kvaliteter, og Blicher gik straks igang med selv at foretage en gendigtning. ${ }^{15}$ ) „Ossians Digte. Oversatte af S.S.Blicher" udkom i to bind i $1807-09$, og denne mesterlige fordanskning overskygger alle andre danske versioner. Sproget er smidigt, fantasifuldt og varieret og stemningen glimrende overført. I beskrivelserne af det melankolske skotske landskab fandt Blicher en form hvori han kunne stobe sine egne skildringer af den mørke og vilde jyske natur, og de mange langtudtrukne billeder, hentet fra naturen, hvormed personernes karakter tegnes, tilegnede han sig ligeledes - mest gribende i „En Landsbydegns Dagbog“.

Det synes at andre forsøgte at komme Blichers oversattelse i forkøbet. I „Nyeste Skilderie af Kjobenhavn" for i 8. april I 807 bragtes en anonym gendigtning af „Slaget ved Lora“, og her meddeltes samtidig: „Med dette Numer folger den for længe siden lovede Prøveoversættelse af Ossians Digte", men Blichers forlægger skyndte sig at indbyde til subskription, og der kom ikke mere end „Prøveoversættelsen“. Derudover lod udgiveren af Alstrups gendigtning indrykke en annonce i „Adresseavisen “ for 6. maj for at minde om dens eksistens på markedet, og ved denne tid udgav også skuespilleren og Shakespeare-oversætteren Peter Foersom en fordanskning af digtet „Berrathon“ i „Iris og Hebe“ for 1808 .

Disse forsøg kan dog langtfra måle sig med Blichers kongeniale gendigtning, og det gælder ligeledes for den tredje og sidste samlede fordanskning af Ossian der blev besørget af F.L.Mynster i $185^{\circ}$, efter at han havde givet prover på sin versificerede omdigtning i Goldschmidts Nord og Syd for 1849 . Ved denne tid var interessen for Ossian-digtene hensygnende - 
den norrøne digtning havde taget pladsen, og sværmeriet for Skotland dyrkedes nu ved læsning af Walter Scott.

Inden for billedkunsten aftegner samme bane sig: fra den forste begejstrede optagethed af de ossianske motiver til den gradvise synken mod næsten total glemsel. Ossian-digtene indbød til illustration, fyldte som de var af episoder der kunne fængsle en historiemaler som søgte nye emner: beretninger om voldsomme kampe, ulykkelig kærlighed og ånders genkomst med en vildsom natur som klangbund. De nordiske malere fik ydermere en lejlighed til at indføre deres hjemlige barskere natur hvor de vante mytologiske eller religiøse scener udspillede sig under sydlige himmelstrøg. Klipper, egeskove og det oprørte hav var ingredienserne i dette heroiske landskab der længe formåede at interessere danske malere sideløbende med deres opdagelse af hvilke kunstneriske muligheder der lå i den nordiske mytologi. ${ }^{16}$ )

De tidligste Ossian-illustrationer, titelvignetterne til forsteudgaverne af „Fingal“ og „Temora“ er primitive rokokovignetter der ingenlunde svarer til digtenes melankoli og ofte gammeltestamentelige alvor. Det hindrede ikke at de blev kopieret $\mathrm{i}$ adskillige europæiske udgaver, og fra den almindelige middelmådighed udskiller sig kun titelbladet til en tysk udgave med engelsk tekst fra 1773 . Denne udgave udkom på Goethes tilskyndelse, og han udførte selv det raderede titelblad hvor teksten yndefuldt kranses af spinkle fyrregrene. Hermed er højlandsstemningen elegant anslået. ${ }^{17}$ )

Der foreligger ikke nogen gennemillustreret dansk udgave af Ossian, men den danske malerkunst kan opvise en forbavsende rigdom af scener fra denne motivkreds - alene på udstillingerne i Charlottenborg vistes mellem 1794 og 183 I tyve sådanne værker. ${ }^{18}$ )

Det er som venteligt Nicolai Abildgaard der indforer Ossian i den danske kunst. Den morkt tungsindige tone i digtene måtte tiltrække hans gemyt, og hans antikvariske videbegær blev stimuleret af deres påståede alde.

I den egenhændige liste over Abildgaards bibliotek i Kgl. Bibl. findes diverse Ossian-udgaver anført, både den engelske version fra 1773 og pater Denis” "Ossians und Sineds Lieder“ fra 1784 , og derudover havde Abildgaard en udgave af Cesarottis italiensk oversættelse i versi sciolti der nød en enestående popularitet ved tiden for hans ophold i Rom. Hertil kom Herders oversættelse i „Von deutscher Art und Kunst“, der også fandtes blandt rigdommene af samtidens forende værker. ${ }^{19}$ )

Kunstakademiets bibliotek ejer idag Abildgaards Ossian-udgaver, og 
det fremgår af den engelske teksts indstregninger og notater at sangene har optaget ham levende. Scener der egnede sig for kunstnerisk behandling er afmærkede, og på enkelte Abildgaard-tegninger i Den kongelige Kobberstiksamling findes citater fra bogen afskrevet. Episoden fra Temora-digtet „Ullin bringer Oscars lig til Skotland“ er forsynet med påskriften „Vid. Temora pag. 19“, og i bogen er stedet indstreget med bly. En anden tegning bærer en afskrift af handlingsreferatet til „Oina-Morul“ og gengiver scenen hvor Ossian efter at have hjulpet en skandinavisk konge, Mal-orchol, i kamp, får hans datter tilbudt. Da han opdager hendes kærlighed til den slagne fjende træder han med scipionisk højmod tilbage og formår faderen til at stifte fred med den besejrede.

Skitsen "Culmins ånd viser sig for hans moder" er ligeledes forsynet med en afskrift, og som i alle Abildgaards illustrationer til Ossian er der lagt megen vægt på nøje at følge tekstens ordlyd, både i gengivelsen af hvirvelvinden der bringer ånden med sig og i de grå hunde, der glammer når gespenster viser sig - et faktum Abildgaard havde mærket sig.

Abildgaards malerier med ossianske temaer udvikler sig gradvis mod det fremragende. På Statens Museum for Kunst findes det tidlige og noget naive "Fingal, der skuer sine fædres ånder" hvor helvedshund, måne og havgus endnu er skrækromantiske rekvisitter. Den samtidige fremstilling af „Ossian i sin hule“ er heller ikke gennemtrængt af nogen overbevisende dæmoni. ${ }^{20}$ )

Langt mere karakterfuldt er et maleri i Stockholms Nationalmuseum af en ung kvinde hvis sorgfuldt sammenknugede gestalt næsten danner en cirkel. På en klippe bag hende hviler genfærdet af en ung mand, og i forgrunden skyder de grå hunde lyn med øjnene, medens månen bag regnskyer oplyser scenen. Billedet kaldes „Malvina ved Ossians lig“, men forestiller ikke nødvendigvis dette par, måske snarere Lorma og Aldo hvis kærlighedshistorie berettes i ,The Battle of Lora “. ${ }^{21}$ )

Intet af disse billeder kan dog måle sig med Kunstmuseets kraftfulde maleri af den blinde Ossian, hvor digtenes vilde og primitive karakter er sammenfattet $\mathrm{i}$ den sorgfulde sangers uskønne men heroiske ansigt. Billedet er dristigt for sin tid ved den kompromisløse fremstilling af den besatte digter - langt fra skønhedens normer men fuld af patos. Stormen pisker i Ossians gråhvide skæg og får hans kappe til at bølge som et stort sejl $\mathrm{i}$ vinden, medens han mindes forfædrenes herlige bedrifter. Venstre hånd rorer harpens strenge, medens spyddet hviler over knæet og det frønnede træ afslutter kompositionen foroven. I den europæiske kunst hører dette maleri til det bedste der skabtes med de ossianske digte som inspiration. 


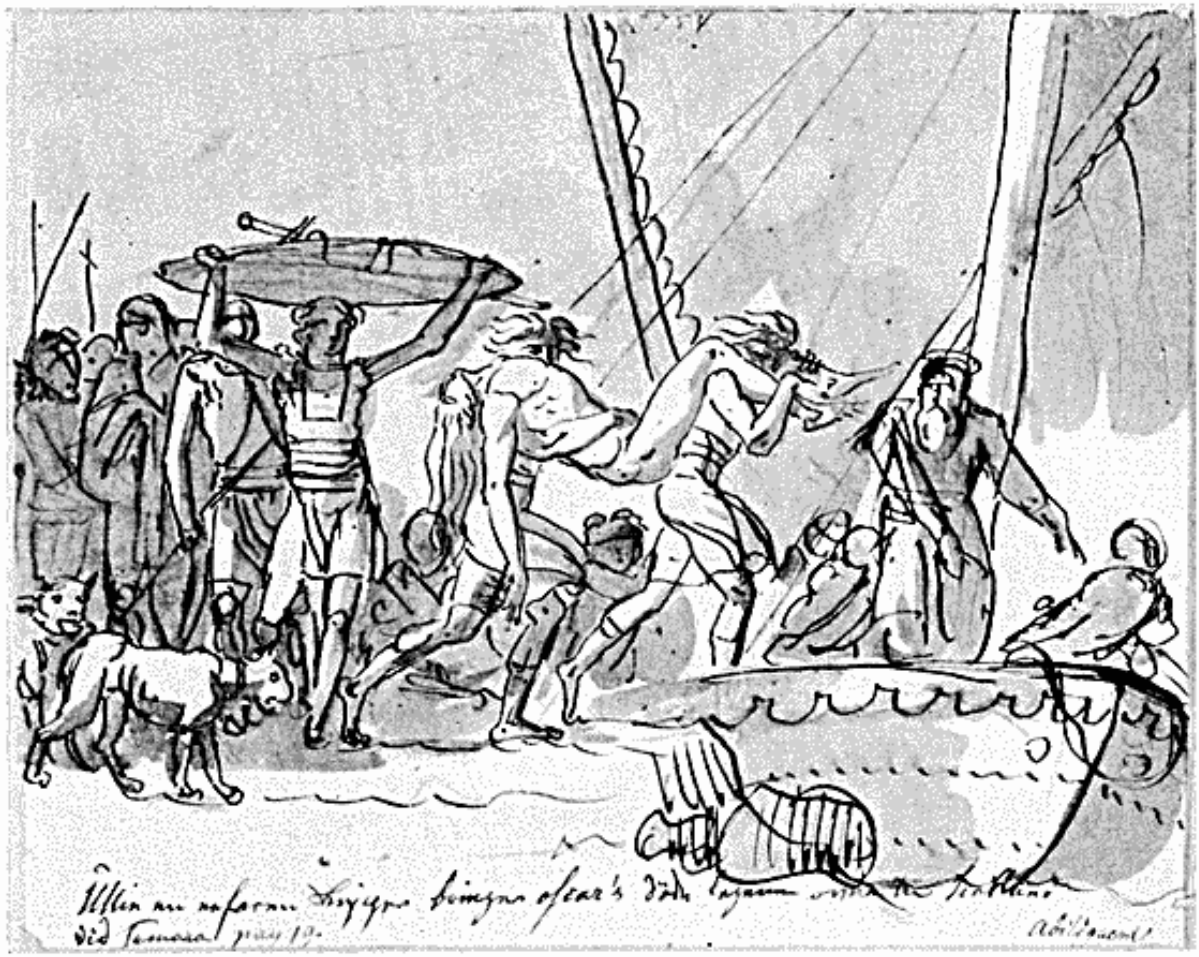

Ullin bringer Oscars døde legeme til Skotland. (Af Temora, I). Skitse af N. Abildgaard. Den kgl. Kobberstiksamling. Originalens storrelse $16,3 \times 20,3 \mathrm{~cm}$.

Omkring ti år efter at billedet var malet gengav J.F. Clemens Ossianmaleriet i et stik der blev udstillet på Salonen i i 794 og som siden vandt stor yndest. Stikket bærer en dedikation fra Abildgaard til den engelske ambassadør i Danmark Sir Hugh Elliott, men var udgivet på Clemens' bekostning som et stykke hvormed han ville præsentere sin kunst for et internationalt publikum. Clemens ejede selv Abildgaards maleri der figurerer på auktionen over hans efterladenskaber i 1832 , medens det populære stik ses på væggen i Ditlev Bluncks fine lille portræt fra 1820 'rne af kobberstikkeren C.E.Sonne. Marstrands interieur fra det Heibergske hjem hvor fru Gyllembourg laser op for agteparret Heiberg, viser at de lod dette højstemt patetiske billede danne baggrund i den christianshavnske dagligstue. ${ }^{22}$ ) Som den mest fremragende danske Ossianillustration anvendtes en gengivelse af Clemens' stik som frontispice i andenudgaven af Mynsters oversættelse fra 1876 .

At Abildgaard har udfort flere ossianske scener end dem vi idag kender til, spores af kataloget over en auktion af effekter fra det abildgaardske 
hjem i 1850 . Her solgtes som nr. 4: „Fingal som giver sin Sønnesøn Oscar sine Vaaben“ og nr. 34: „Oscar. Studie“, og desuden udstillede han på Salonen i I 794 "Culmins Gienfærd viser sig for hans Moder".

Alle de kendte abildgaardske fremstillinger af Ossian-scener tilhører den tidlige del af hans produktion, et træk som genfindes hos de fleste af de kunstnere der har givet sig af med at illustrere de skotske heltes bedrifter. Blandingen af kampiver og sværmerisk melankoli finder bedst genklang i det ungdommeligt følelsesfulde sind, og det er betegnende at de unge slesvigere ved akademiet på Charlottenborg ofte behandlede de ossianske optrin, da deres kunst i det hele var mere eksalteret end de danske elevers.

En af Abildgaards vrangvillige elever var slesvigeren Asmus Jacob Carstens der trods sin modvilje mod de kunstneriske lareanstalter modtog afgorende indtryk af hans kunst. Han interesserede sig tidligt for den nordiske mytologi og var blandt de første der indførte emner herfra i sin kunst, men det vides ikke om han her i Kobenhavn gav sig af med at illustrere Ossian. En tegning udfort i Lübeck i 788 med motivet „Ossian og Alpins søn " kendes derimod, og i 1796 malede han i Rom Kunstmuseets billede af „Fingal i kamp med Loda“. Stemningen i billedet er oppisket: Lodas vældige grå skikkelse raser i dysten med den rustningsklædte Fingal, men trods øjne der gløder under buskede bryn og elementernes rasen er der noget hult ved billedets patos. Der er mere valde i selve digtet "Carric-thura": „A blast came from the mountain, on its wings was the spirit of Loda. He came to his place in his terrors, and shook his dusty spear. His eyes appear like flames in his dark face! his voice is like distant thunder".

Billedet blev købt af Friederike Brun, der var en stor ynder af Carstens' kunst - ligesom hun i det hele ved sin germanske orientering indtager en særstilling blandt danske kunstkendere. På dette tidspunkt udøvede Carstens' kunst og oprørske person stor indflydelse på de modtagelige unge kunstnere i Rom, heriblandt Thorvaldsen og tyroleren Josef Anton Koch, der begge aftegnede mange af hans skitser. Koch arbejdede i flere perioder med Ossian-stoffet, som han påtænkte at anvende i en gennemillustreret udgave, og 53 af disse tegninger findes på Thorvaldsens Museum, medens en senere serie på 37 blade er i Bibliothek der Akademie der bildenden Künste $\mathrm{i}$ Wien. I Rom forberedte man som hyldest til

Pá modstäende side: J. F. Clemens' stik efter N. Abildgaards maleri af Ossian. Originalens storrelse $32 \times 23,2 \mathrm{~cm}$. I reduceret gengivelse og uden dedikation anvendt som frontispice til F. L. Mynsters Digte af Ossian, 2. udg. 1876. 


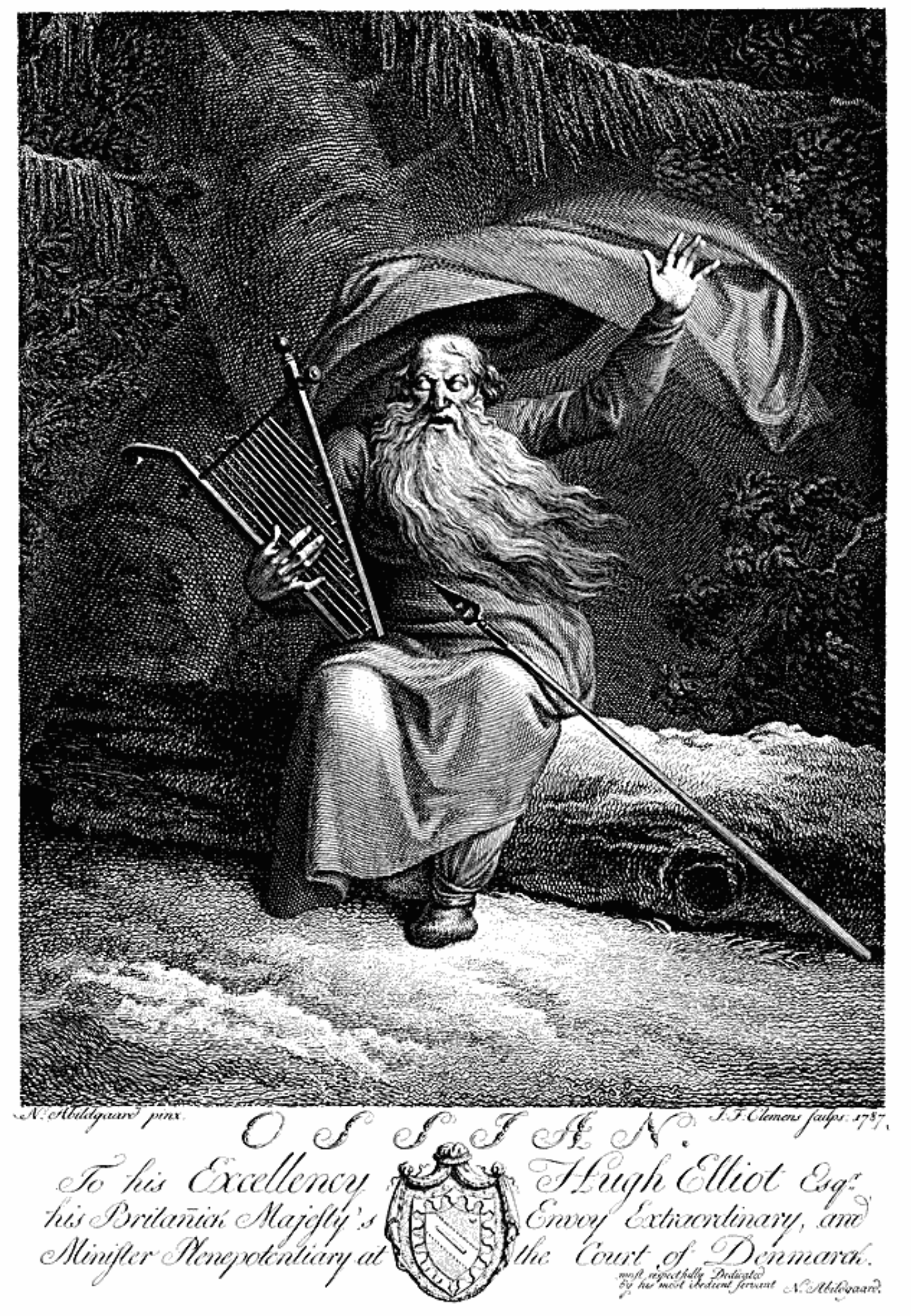


Napoleon en pragtudgave hvor Kochs tegninger skulle stikkes af Tommaso Piroli der var berømt over hele Europa for sine omridsstik efter Flaxman til Odysseen og Iliaden. ${ }^{23}$ )

Den idé at skænke Napoleon en Ossian-udgave var ganske nærliggende, idet hans forkærlighed for denne skjald var velkendt. Napoleon havde læst Ossian fra sin tidligste ungdom, og på overfarten til Egypten medbragte han en oversættelse der lå ved sengen i hans kahyt. Han talte ofte med glød om denne læsning som han satte over Homer, og reciterede endog ved lejlighed udvalgte stykker deraf. Til biblioteket i Malmaison bestiltes år 1800 hos malerne Gérard og Girodet scener af Ossian, og til udsmykningen af Quirinalet i Rom hvor kejseren planlagde sit indtog, udforte Ingres i 1812 et maleri af Ossian der skuer sine forfædres ånder - medens Thorvaldsen fik Aleksandertoget i opdrag. ${ }^{24}$ )

Den påtænkte udgivelse af Ossian med Kochs illustrationer kom derimod ikke istand, da pladerne gik tabt for bogen tryktes, hvilket må beklages, eftersom mange af tegningerne er ganske fremragende. De talrige Koch-skitser i Thorvaldsens Museum er ikke af egal kvalitet og antagelig heller ikke samtidige. Nogle fremstillinger slutter sig nøje til Carstens' kunst, heriblandt „Fingals kamp med Loda“ der næsten kopierer Carstens' komposition, medens Koch til adskillelse fra sin forgænger søger at give en mere troværdig arkæologisk gengivelse af de forskellige optrin. Han medtager i den nævnte tegning stensætningen („the circle of Lora"), der skulle være det hedenske kultsted - men at være tro mod historiske detaljer i et vark der med dødsforagt blander utallige perioder, er naturligvis et umuligt forehavende, og de primitive elementer i Kochs tegninger er fortrinsvis hentet fra den romanske og gotiske arkitektur. Iovrigt er Kochs tegninger i langt højere grad end de fleste andre Ossianillustrationer meddigtende, og det er lykkedes ham kraftfuldt at karakterisere de personer og optrin der i bøgerne ofte beskrives vagt og enslydende.

At unge danske kunstnere havde oje for kvaliteterne i de kochske tegninger ses i maleren C. G. Kratzenstein Stubs arbejder. Han opholdt sig i 1810-1 I i Rom og havde her nær forbindelse med Thorvaldsen, og at han gjorde sig bekendt med dennes samling af Ossian-illustrationer spores $\mathrm{i}$ hans tegninger hvoraf en del efter hans tidlige død udkom som omridsstik i bogen „Haandtegninger af Krazenstein Stub“ I-IV, I8I7, (nyt oplag 1844).

Stubs tegnemåde minder stærkt om Kochs, og blandt enkelte direkte lån kan nævnes den svævende kvindefigur i Stubs „Malvinas Aand opfordrer Fingal til at drage i Kamp" der er overtaget fra en tegning 


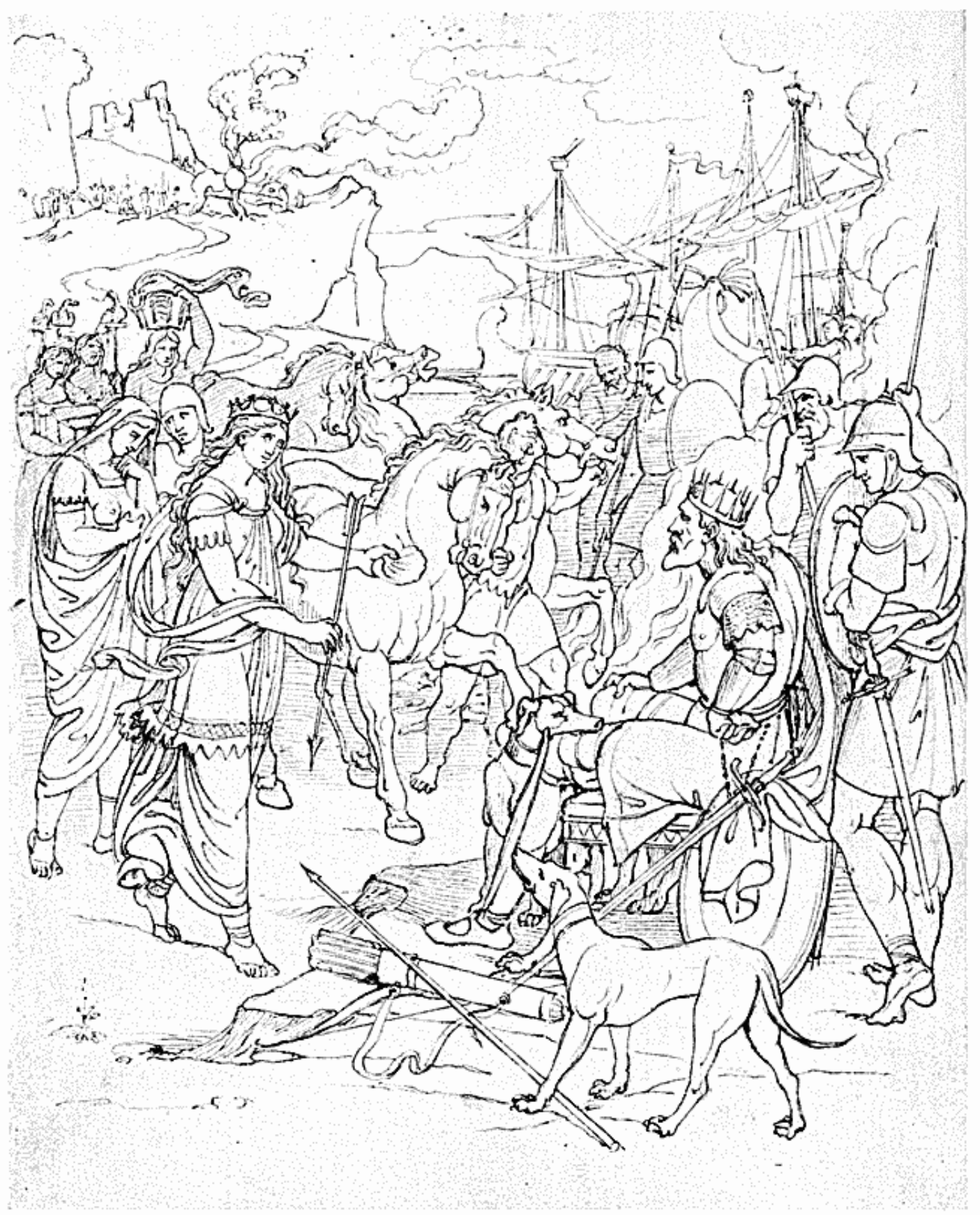

Bosmina, Fingals datter, kommer til Soras fyrste for at mægle fred. (The Battle of Lora). Tegning af J. A. Koch i Thorvaldsens Museum. Originalens storrelse $23,7 \times 19,1 \mathrm{~cm}$. 
af Koch. Stubs „Alcyone“ på Kunstmuseet står også i nøje forbindelse med de mange figurer, hyllede i kapper, der findes hos Koch, ligesom arkitekturens preg af middelalder snarere end oldtid og mange enkeltheder i dragter og våben er hentet i hans skitser. Stubs mest selvstændige komposition er tegningen af Agandecca der udånder i sin elskede Fingals arme, stukket ned af sin egen fader, den skandinaviske kong Starno. ("She fell, like a wreath of snow, which slides from the rocks of Ronan; when the woods are still, and the echo deepens in the vale").

I Stubs kunstneriske produktion indtager de ossianske emner en vagtig plads, og hans biograf P. E. Müller skriver i sin opsats „Krazenstein Stubs Minde" i „Athene" for $18 \mathrm{r} 6$ om den nyligt af tæring bortrevne unge kunstner: „De Digte, han som Kunstner oftest læste var Ossians“. Friederike Brun der vel forstod denne forkærlighed, skriver om tegningen „Fingals Kamp med Aanden Loda“ fra I814: „En beundringsværdig Fremgang hos Kunstneren er synlig i dette Sujet ved hvis Udførelse han har stridt om Palmen med den forevigede Carstens ". ${ }^{25}$ ) Friederike Brun havde forøvrigt også interesseret sig for den unge kunstner Philipp Otto Runge der i 1804 fik bestilling på illustrationer til en udgave af Ossians digte oversat af Leopold von Stolberg, men de så ikke dagens lys.

Fra denne emnekreds hentede endelig Kratzenstein Stub motivet til sin kunstneriske svanesang „Ossian og Alpins Søn“ på Kunstmuseet, der er signeret og dateret 1816 med tilføjelsen „maaeske det Sidste“. Denne fremstilling adskiller sig fra Abildgaards ved sit elegiske præg og en broget kolorit og er ganske interessant og selvstændigt i forhold til traditionen. Er Alpins søn lidt sødladent fremstillet, er Malvinas ånd der griber i harpens strenge til gengald et beundringsværdigt stykke genfærd, særlig da det ofte kniber for malerne at få de dødes ånder til at vække gysen eller medynk - nogle gespenster kalder endog på smilet. ${ }^{26}$ )

Kratzenstein Stubs maleri repræsenterer en overgangsperiode i den danske kunsts historie, tiden mellem Abildgaard og Eckersberg, og i den nævnte mindeartikel betoner P.E.Müller stærkt hans selvlærthed og frakender næsten Abildgaard enhver indflydelse på den unge maler - ganske i strid med virkeligheden, men i overensstemmelse med den da moderne despekt for akademierne. Det hedder: „Efter at være bleven Student gik han et Par Maaneder paa Abildgaards Malerstue, hvorved han især blev bekiendt med det mekaniske i Farveblandingen. Det er al den umiddelbare Undervisning, han nogensinde modtog.

Pä modstäende side: Fingal, Agandecca og Starno. (Fingal, III). Stik afW. H. Wentzler efter C. G. Kratzenstein Stub, 1817. Originalens storrelse $29 \times 42,5 \mathrm{~cm}$. 


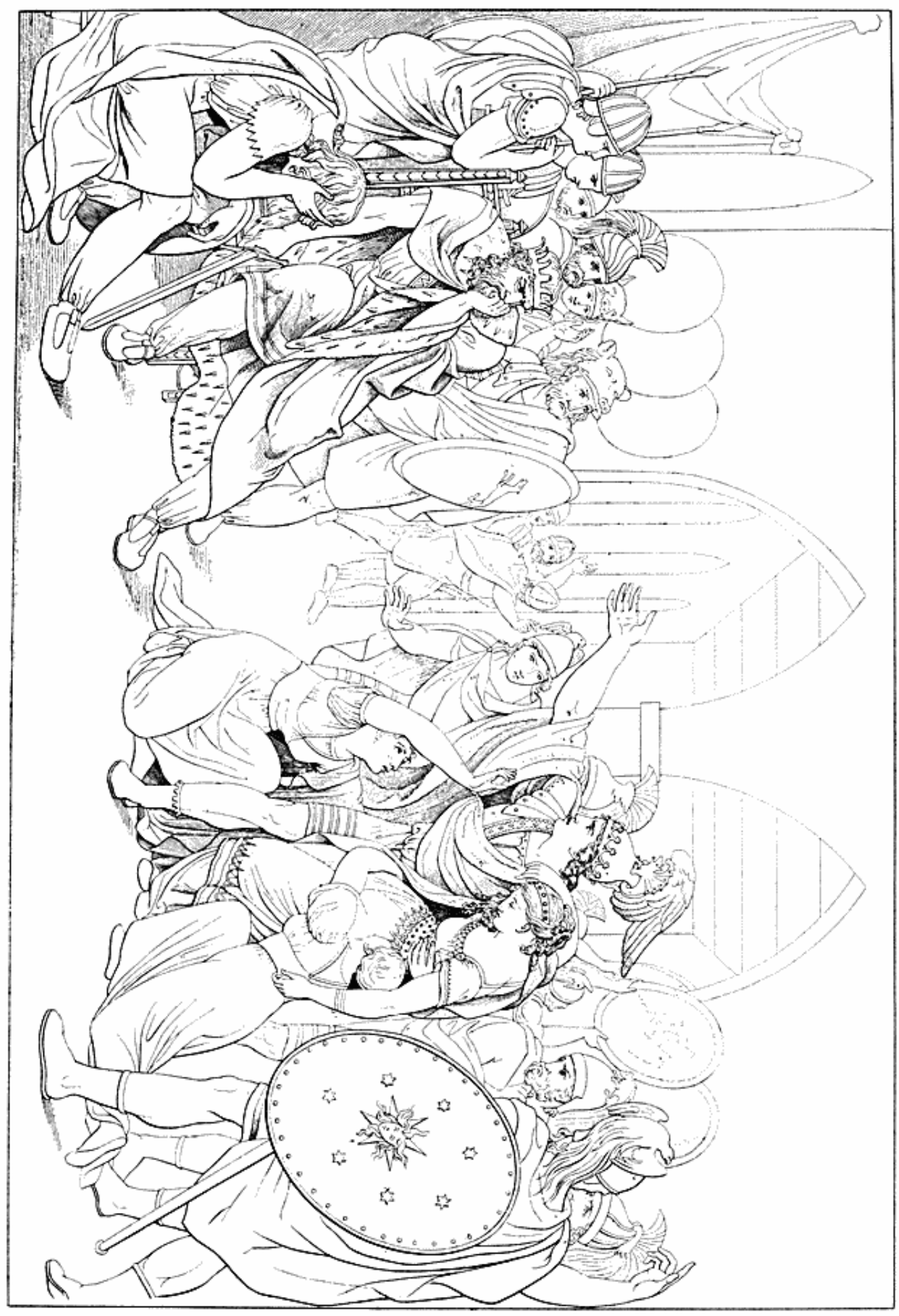


Geniet groer ei i et Drivhus, konstig Varme

Udklækker ei den underskiønne Frugt

... Ved selv at danne sig, undgik han derimod de stive Academifigurer og kolde Steenansigter. “ ${ }^{27}$ )

En anden Abildgaard-elev, Christian Fædder Høyer, forblev mere loyal mod sin læremester, men måtte derfor se sig forvist til en stadig mere afsides plads i den danske kunstverden, medens den eckersbergske retning triumferede. Høyer indlod sig snart i bitre stridigheder med Kunstakademiet, til megen græmmelse for ham selv, da han aldrig opnåede den eftertragtede professorstilling.

I Høyers maleri kom Ossian til at spille en betydningsfuld rolle, ja ingen dansk maler beskæftigede sig så vedholdende med denne digtning som han. Det fremgår af en brevkoncept i Kgl. Bibl. at han allerede arbejdede med disse emner da han i sin ungdom opholdt sig i Rom hos Thorvaldsen. Koncepten, der er dateret den 31 . august 1808 , findes $i$ de abildgaardske papirer og er stilet til baron Schubart, over for hvem Høyer aflægger regnskab for de tre foregående års arbejde. Blandt de fuldførte arbejder nævner han foruden „Sokrates i Fængslet“ og „Hero ventende Leander“ (begge i Statens Museum for Kunst) at han „Har giort forskiællige Compositioner, flere af Ossian “. ${ }^{28}$ )

Hjemvendt til Danmark havde han den triumf at sælge fire malerier fra udstillingen i I8I 2 til kongehuset: foruden de nævnte klassiske sujetter, efter kataloget: „Cathmor. Sulmalla forestilte sig Krigens Onde, ilte til sin Elsker Cathmor, Fyrsten af Erin, for at formaae ham til at giøre Fred med Fingal; men den ædle Helt overbeviist om at handle rigtig var ikke til at overtale." og "Sulmalla. Da alting var stille ventede Sulmalla sin Elsker Cathmor, thi han havde lovet hende at komme, men Cathmors Geist viste sig for den gamle Digter Clomal." Sulmalla og Cathmor gengives $\mathrm{i}$ det forste billede $\mathrm{i}$ et landskab ved havet hvor et ensomt stormombrust træ ses i baggrunden, medens en meteor skærer sig igennem glødende skyer bag hvilke halvmånen skimtes. I skyerne drager en åndehær af krigere frem, og digtenes stemning er ret troværdigt overført til maleriet (ill. s. 24). I den noget svagere scene med den gamle Clomal sidder den sortlokkede Sulmalla ved hans side $\mathrm{i}$ en hule ved havet. Harpen og hunden hviler ved bardens fod, og Cathmors genfærd kommer tilsyne ved stranden (ill. s. 25).

Disse to billeder hører med deres sørgmodige tone til det bedste $\mathrm{i}$ Høyers produktion, men efter den første ungdoms medgang svigtede publikums interesse for hans Ossian-scener og ved auktionen over hans 


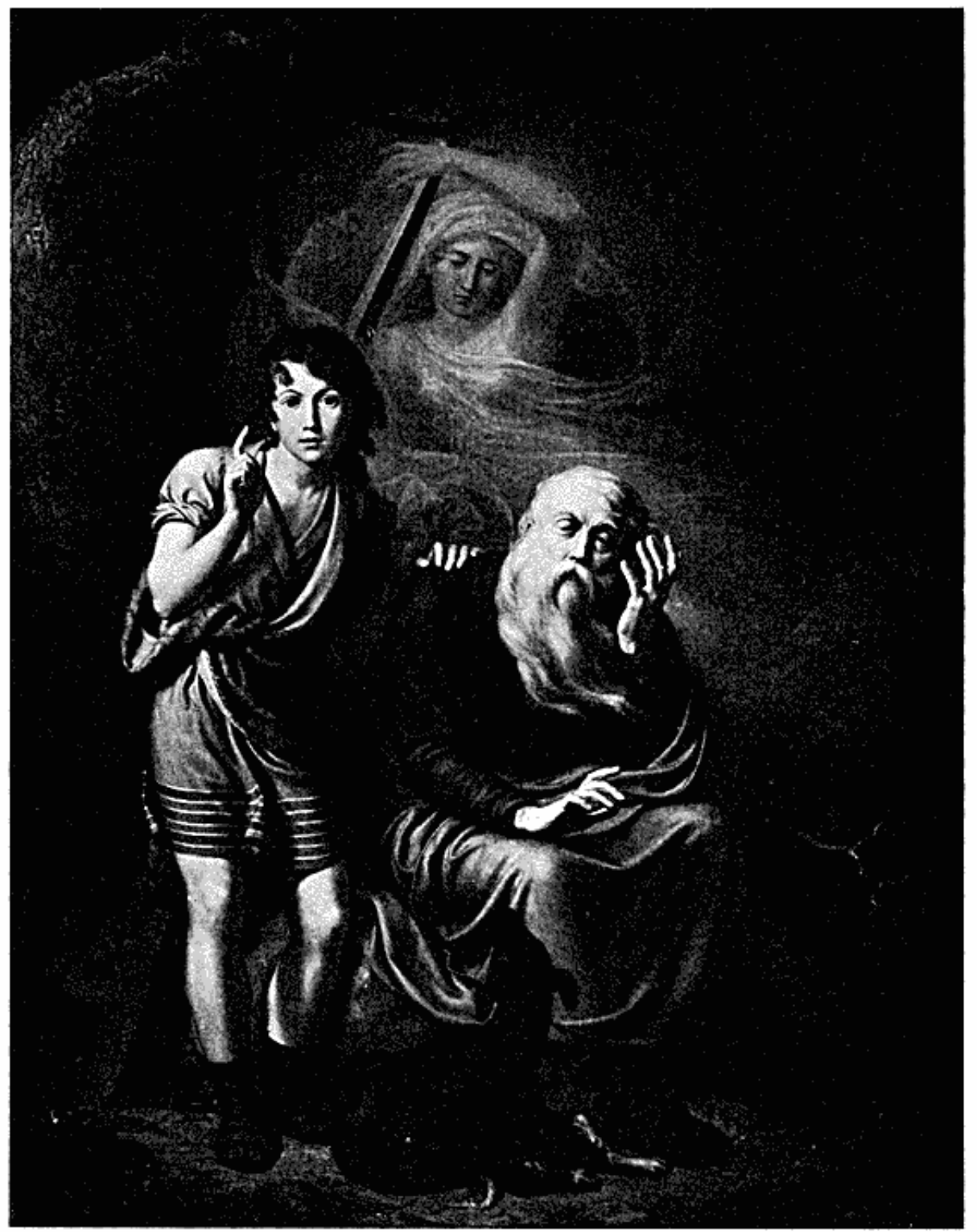

Ossian og Alpins Son. (Berrathon). Maleri af C. G. Kratzenstein Stub, dateret 1816. Statens Muscum for Kunst. Originalens størrelse $I_{1} 5,5 \times 89,5 \mathrm{~cm}$. 


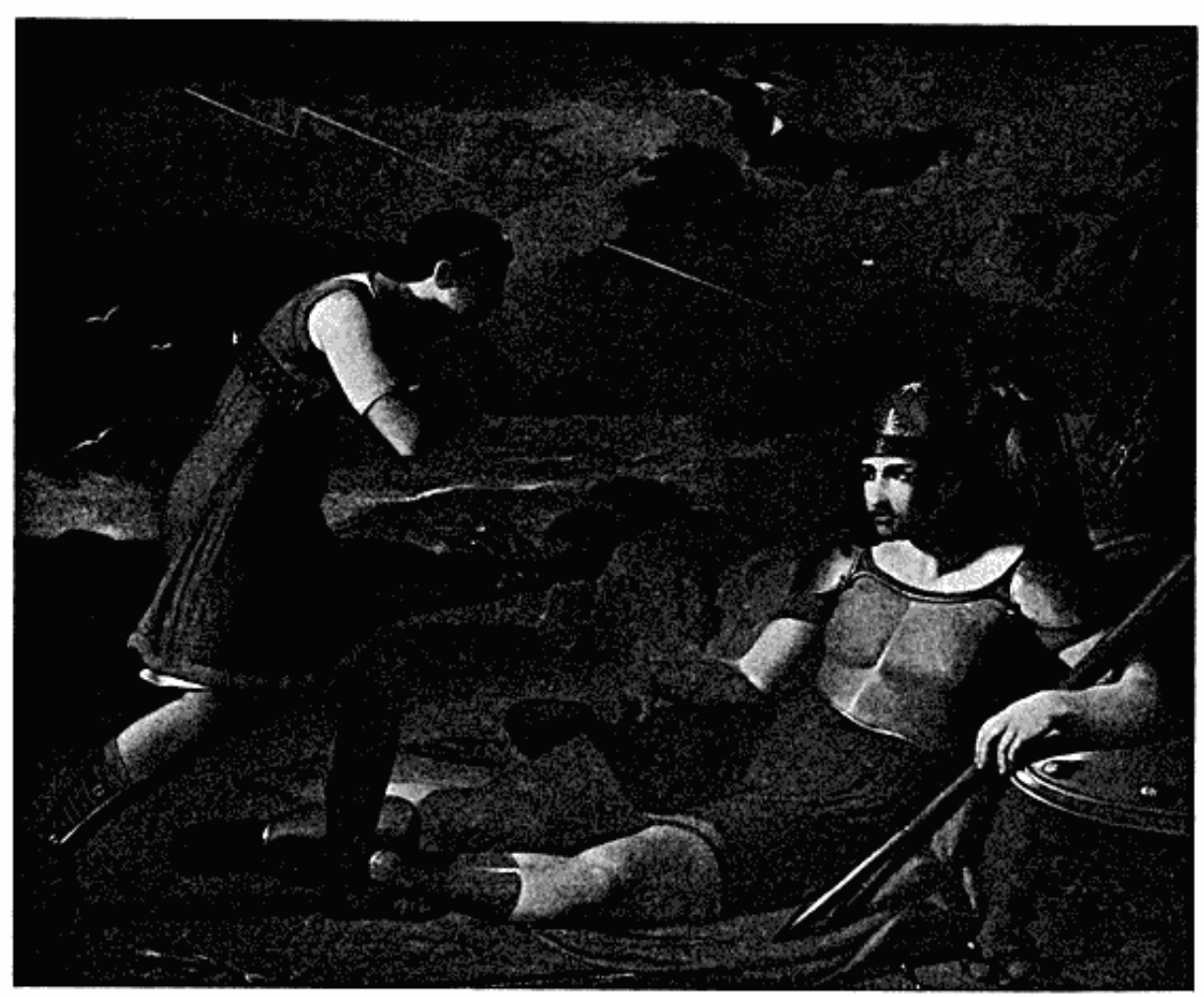

Cathmor. Sulmalla forestilte sig Krigens Onde, ilte til sin Elsker Cathmor, Fyrsten af Erin, for at formaae ham til at giore Fred med Fingal; men den adle Helt overbeviist om at handle rigtig var ikke til at overtale. (Temora, VIII). Maleri af C. F. Høyer. Statens Museum for Kunst. Originalens storrelse $184 \times 227,5 \mathrm{~cm}$.

bo i 1855 bortsolgtes ialt ${ }_{15}$ malerier og 17 tegninger fra denne motivkreds. Et par af disse malerier var udkast til dekorationen af Københavns Universitets forhal som arkitekten Peder Malling havde givet bestilling på hos Høyer, hvorved han langt overskred sin kompetence for at hjælpe en ven. En langvarig og bitter offentlig strid om udsmykningen fulgte, og Malling formåede endog Abildgaards enke til „med et ligesindet - for et højere Maal aandende - Samfund af Dannequinder" at gå til kongen med en støtteadresse for Høyer, men denne og al anden intervention til hans fordel var forgxves. Dekorationsopgaven tilfaldt Constantin Hansen og Hilker, hvilket var endnu et bittert nederlag for Høyer der allerede havde lagt et stort arbejde i udsmykningen, hvoraf enkelte dele endog nåede at blive sat op for den endelige afgorelse faldt. Den græske gudeverden holdt sit indtog på Universitetet i stedet for Høyers ossianske 


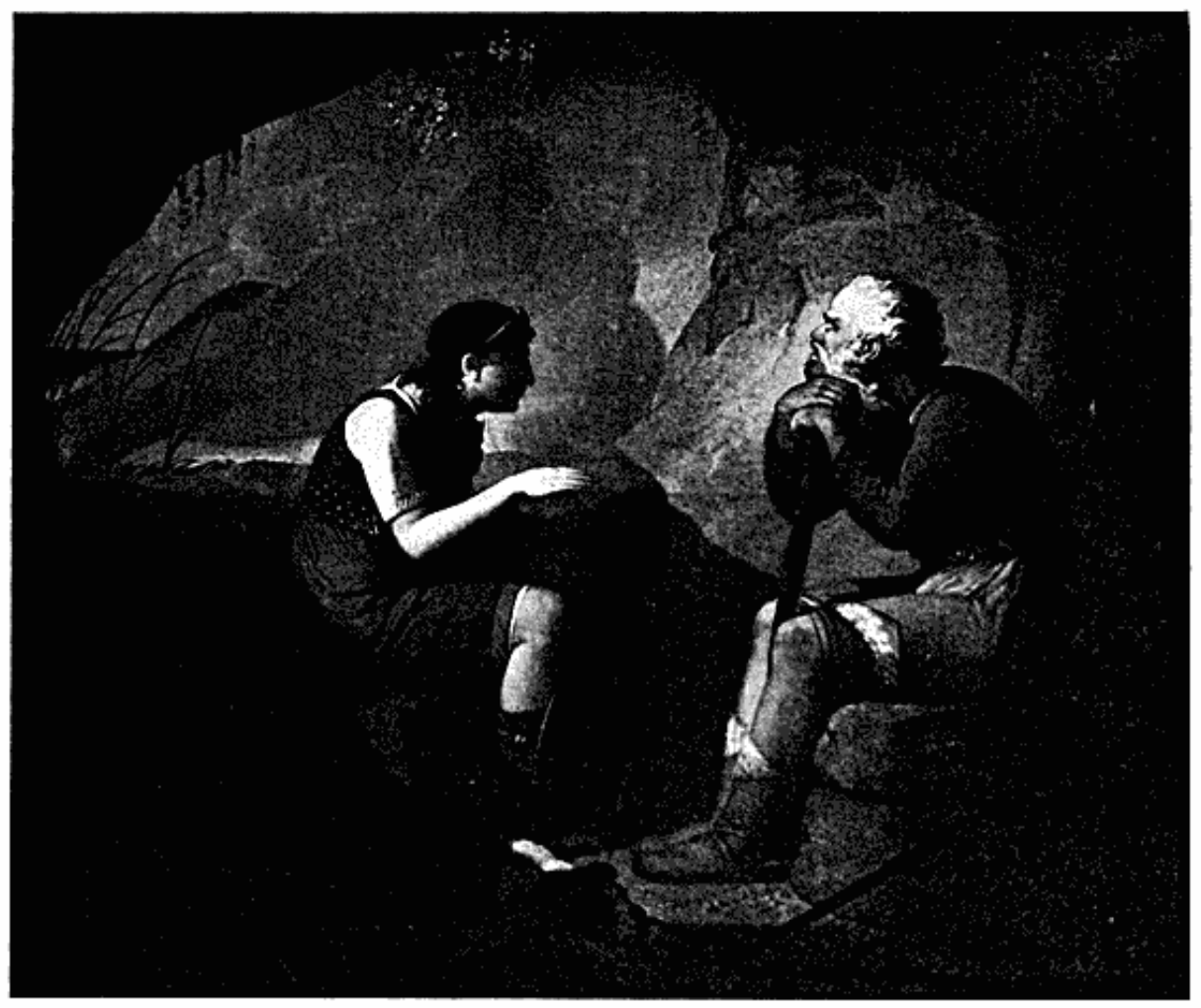

Sulmalla. Da alting var stille ventede Sulmalla sin Elsker Cathmor, thi han havde lovet hende at komme, men Cathmors Geist viste sig for den gamle Digter Clomal. Maleri af C. F. Hoyer. Statens Museum for Kunst. Originalens storrelse $184,5 \times 222 \mathrm{~cm}$.

scener „Fingals Datter kommer til Soras Fyrste for at magle Fred“ og „Ossian holder Foredrag for en flygtende Christen “. ${ }^{29}$ )

Historiemaleriet stod dog endnu overst på maleriets officielle rangstige, og derfor ses det, at de unge akademielever lejlighedsvis afbilder helteoptrin efter Ossian blandt andre elementer i det akademiske skoleridt. Til disse pligtarbejder tor man vel regne Eckersbergs forsvundne „Lorma og Aldo“, udstillet for han gav sig på den skelsættende udenlandsrejse. I I 820'rne kan derimod spores en mere dybtgående bølge af fornyet begejstring for den ossianske poesi, især blandt de slesvig-holstenske akademielever hvis litterære og kunstneriske smag ved denne tid var særdeles følelsesfuld, ja eksalteret.

Den unge H.W. Bissen der endnu ikke havde bestemt sig for at blive billedhugger, foretog med Albert Küchler og Jorgen Sonne sværmeriske 


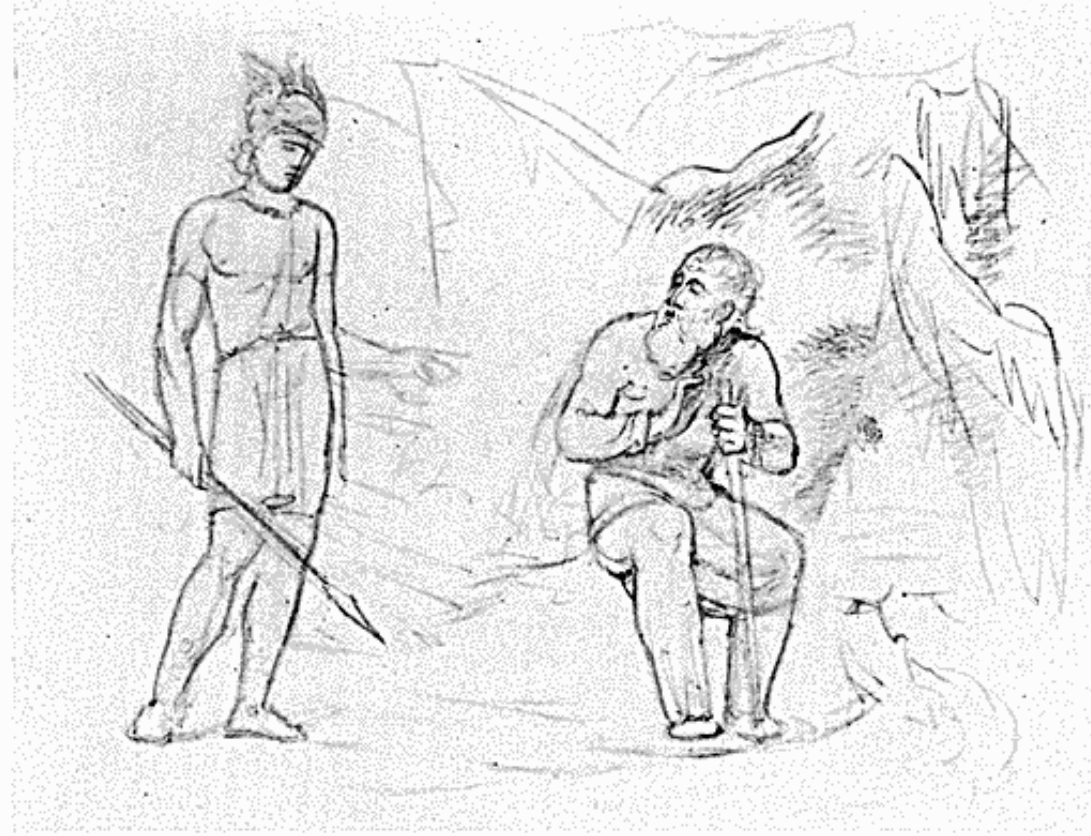

Ossiansk scene. Tegning i skitsebog udfort af Constantin Hansen omkring $\mathbf{r} 826$. $\mathrm{Kgl}$. Bibl. Originalens storrelse $18,5 \times 22,6 \mathrm{~cm}$.

udflugter i de sjællandske skove og tog stade i træerne for at tegne skitser. Han malede i ${ }_{1} 82$ I billedet „Ossian under et egetræ med Malvina og Alpin “, og fra samme tid stammer en skitsebog i Ny Carlsberg Glyptotek, hvori Bissen aftegnede enkelte ossianske helteoptrin. Küchler tumlede med samme emner; han skrev den 26. november I 824 til Bissen: „jeg arbeider i denne Tid paa et Stykke af Ossian med to Figurer, som jeg haaber at faa Færdig om et paar Uger “,30) og dette år udstillede han på Charlottenborg en Ossian-scene som ikke kendes længere. De få Küchlertegninger efter Ossian fra denne tid som findes i Kobberstiksamlingen er meget naive, og Küchler indså snart at hans evner lå andetsteds end i det heroiske figurmaleri. Bissen derimod vendte senere tilbage til Ossian som han gengav i en fin lille statuette, nu i Ny Carlsberg Glyptotek. Den blinde barde er fremstillet som et modstykke til en lignende skitse af Homer - „'Homère du Nord“, som Mme de Staël udtrykte det, modstillet den graske sanger. Bissens fremstilling er meget behersket $\mathrm{i}$ forhold til de tidligere Ossian-skikkelser, idet sorgfuldheden kun er antydet gennem figurens holdning (ill. s. 28).

Til ungdomstidens Sturm und Drang hører derimod Constantin 


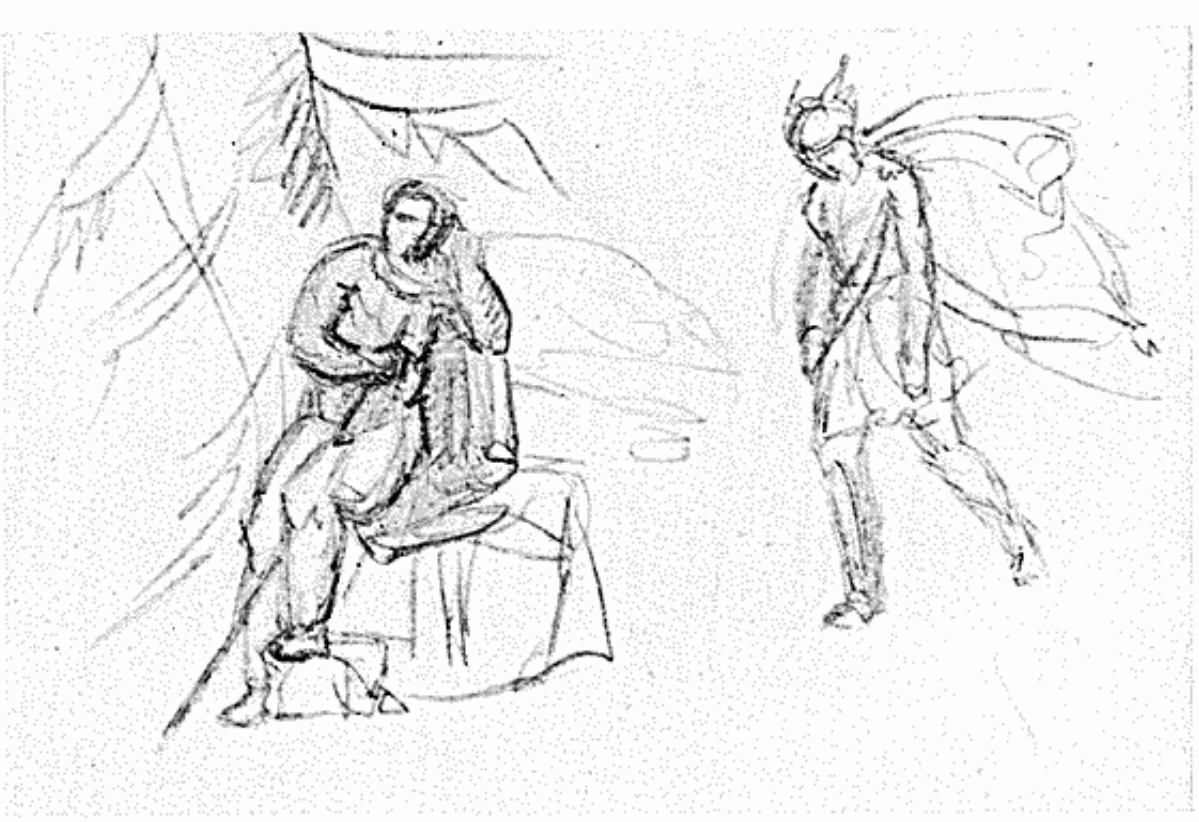

Ossiansk scenc. Tegning i skitsebog udfort af Constantin Hansen omkring 1826 . $\mathrm{Kgl}$. Bibl. Originalens størrelse $10 \times 17 \mathrm{~cm}$.

Hansens begejstring for Ossian-læsningen, som han dyrkede tilligemed Walter Scott og Ingemann, for dog snart at vende sig mod Shakespeare, Homer og Goethe. Hans fader, Hans Hansen, havde i I 823 udstillet en kopi efter Kratzenstein Stubs Ossian-maleri ${ }^{31}$ ) der lige så lidt kendes idag som Rørbyes ossianske scene fra udstillingen i i 825. Fra Constantin Hansens efterladenskaber haves derimod i Kgl. Bibl. en del skitsebøger der giver meget værdifulde oplysninger om næsten hele hans skaberperiode, og de tidligste indeholder modeltegninger og antikstudier tillige med en del skitser til søstrenes portrætter der daterer dem til o. I826. Heri findes også enkelte Ossian-studier, således Fingals kamp med Loda og nogle gengivelser af Ossian med den unge helt Oscar. Tegningerne bærer naturligvis præg af at være udført af en ganske ung elev, men de viser trods alt, i lighed med mange af de øvrige skitser, at Constantin Hansen ville komme til at få et mere sikkert greb om de heroiske figurfremstillinger end de fleste af hans samtidige. Ossian vendte han dog ikke tilbage til, da han som de ovrige danske kunstnere blev stærkere grebet af den nordiske gudeverden. ${ }^{32}$ )

Til gengæld marker man ikke meget af lovens klo i det sidste danske 


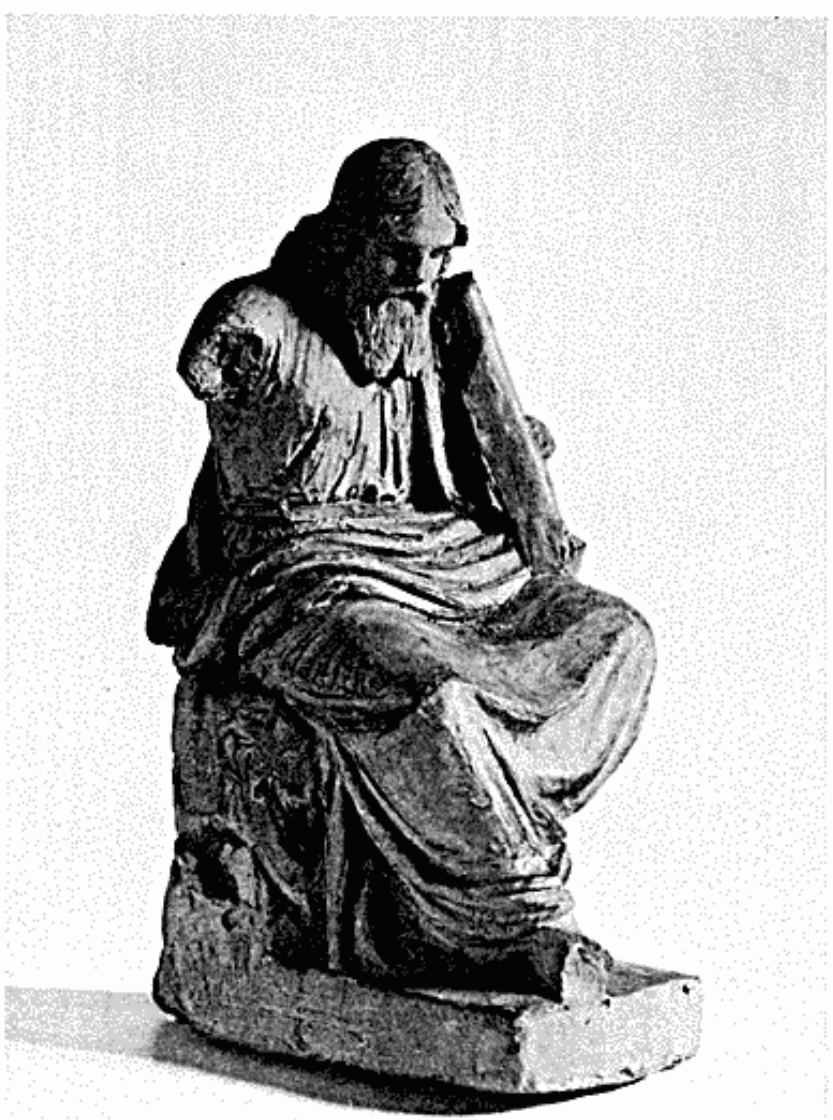

Statuette af Ossian i brandt ler, udfort af H. W. Bissen omkring 1835 . Ny Carlsberg Glyptotek. Originalens højde $15,4 \mathrm{~cm}$.

maleri efter Ossian. Det er Kunstmuseets billede af F.L. Storck fra udstillingen i 1828 , efter beskrivelsen i „Temora " af den unge lyslokkede helt Oscars død, da han på et togt til Irland blev lokket i baghold af den træske Carbar. Det teatralske billede gengiver en strand, hvor Oscar udånder i Ossians favn, begrædt af den gamle kæmpe Fingal („Hans hvide Skjæg hvinte i Vinden“). Med dette lidet gloriøse stykke uddør Ossian-illustrationen i Danmark, og det havde varet en sørgelig epilog, om ikke inspirationen fra disse kvad uventet havde befrugtet en helt anden kunstart, musikken. Men i $184 \mathrm{I}$ uropfortes Niels W. Gades ouverture „Efterklange af Ossian“ i Musikforeningen, og dette værk opnåede europaisk berømmelse. Hvor Abildgaards kraftfulde fortolkning af den ossianske poesi kun udøvede sin virkning på ganske få elever, opnåede 
Gades musik at bringe bud om den frugtbare virkning af de skotske sange til hele det musikelskende Europa og bidrager endnu idag til ihukommelsen af Ossians.

\section{NOTER}

(1) I dansk oversattelse blev citatet motto for den blinde forlægger C.F.W. Lahdes „Ossian. Et Ugeblad“, 1826. - (2) Kgl. Bibl. ejer forsteudgaver af sảvel „Fragments“ som „Fingal“ og „Temora“, foruden megen anden Ossian-litteratur. Eksemplarerne af ,Fingal“ $\mathrm{og}$ „Temora“" overgik til kongens eje ved auktion i 1788 over Otto Thotts samling. Den store rigdom af Ossian-værker omtales passkonnende i dedikationen til D.G.Moldenhawer i Joh. Gurlitts bog Ueber Ossian, Hamburg \& Magdeburg 1802. Et udkast til en Ossian-bibliografi er gjort af George F. Black med: Macpherson's Ossian and the Ossianic Controversy, Bulletin of the New York Public Library, XXX, June \& July 1926, pp. 424 ff. og 508 ff. - (3) Ossians indflydelse på den europæiske litteratur behandles af P. van Tieghem: Ossian et l'Ossianisme dans la littérature européenne au xvine siècle, La Haye 1920 (Neophilologische Bibliotheek, IV, Groningen). En udforlig udredning af de franske forhold i samme forf.s Ossian en France, I-II, Paris r917. Påvirkningerne i Skandinavien undersogt i Th. Hasselqvist: Ossian i den svenska dikten och litteraturen, Malmö 1895 og Anton Blanck: Den nordiska renässancen, Stockholm I9II.

(4) Georg Zoëga: Briefe und Dokumente, hrsg. von Øyvind Andreasen, I, 1775-1785, Kph. 1967 , p. 85. Niels Schou anfører om Zoëgas frerden i Göttingen 1779-90: „Han læste meget for sin Fornøielse, især Poesi. Af Homer og Ossian havde han anskaffet sig tvende meget smaa Udgaver, og uden een af disse i Lommen gik han sielden ud af sit Værelse". Det var almindeligt at sammenstille Homer og Ossian, ja enkelte enthousiaster satte endog Ossian højest, heriblandt Baggesens ven greve Adam Moltke, cfr. Axel Pontoppidan: Adam Gottlob Detlev Greve Moltke, 1939, p. 74. Et brev fra Zoëga til Chr. Birch, 6. marts 1780, skrives i en grotte nær Kassel ,mit Ossian in der Hand" (Briefe und Dokumente, I, p. 186) og i 1777 havde han besegt Ossian-oversatteren pater Denis i Wien og var meget begejstret for denne elskverdige mand der „vollkommen die Kunst verstand, das Interesse eines Gespräches zwischen sich u. der mitredenden Person zu theilen", ibid. p. 54. - (5) Friederike Brun: Wahrheit aus Morgenträumen, Aarau I824, p. I45. - I Friederike Bruns stambog på Bakkehusmuseet findes to Ossianillustrationer: nr. 22 Ossian og Malvina af den tyske kunstner Friedrich Rehberg, udfort i Rom 1803 , og nr. 109 en ossiansk scene udfort af Adam Müller, dat. 28. October 1827 .

(6) Efterladte Papirer fra den Reventlowske Familiekreds v. Louis Bobé, IX, 1922, p. 6. - (7) Se: Ernst Frandsen: Johannes Ewald. Et Stykke dansk Aandshistorie, 1939, og Helge Toldberg: Det nordiske Element i Johannes Ewalds Digtning, Studier fra Sprog og Oldtidsforskning, 195, 1944. Beretningen om den planlagte ekspedition giver Ewald i et brev til P.F.Suhm, se E.s Samlede Skrifter, IV, 1919, pp. $375 \mathrm{ff}$. 
Brevet nu i Kgl. Bibl. NkS 4554, $4^{\circ}$. - (8) Tidens store Ossian-interesse gav sig iøvrigt udtryk på mange mảder, bl. a. i engelsk-undervisningen. I Boghandlerne Lycke og Rønkilds lejebibliothek i København fandtes 1788: Tales of Ossian for Use and Entertainment. Ein Lesebuch für Anfänger im Englischen. Mit beigefügten historischen, statistischen und genealogischen Erläuterungen von Johann Balbach, Nürnberg 1784 . Almenheden kunne også studere Ossian i Suhms offentlig tilgangelige bibliotek eller lăne en Ossianudgave fra 1777 i biblioteket i Drejers Klub, se: Fund og Forskning VII, 196o, p. $9^{2}$.

(9) Hertil kommer Finn Magnusens Forseg til Forklaring over nogle Steder af Ossians Digte, mest vedkommende Skandinaviens Hedenold, 1814, hvori han, ikke helt korrekt, angiver at flertallet af kritiske lærde er af den overbevisning at digtene er gamle. Kgl. Bibl.s eksemplar er dediceret K.L. Rahbek og forsynet med blyantsindstregninger. - (10) I subskriptionsplanen (p. 544) hedder det: „Endog paa Dansk have vi enkelte Stykker deraf; men disse ere faa, og desuden adspredte." Et brudstykke findes i C. Pram: Samling af Oversattelser i Prosa til Nytte og Fornoielse, I, 1788 , pp. 22 I ff., hvor digtet „Calthon og Colmal“ er oversat. En anmeldelse findes i Nyeste Kjøbenhavnske Efterretninger nr. 10 for ${ }_{17} 89$, pp. $157 \mathrm{ff}$. hvor det hedder: „Den stille, høitidelige Tone, og de usadvanlige, starke Billeder, der udmarker Ossians Sange, hersker og i denne, som oftere maa lases og foles." P.F.Suhm bringer også en langere oversæettelse i Om Odin og den hedniske Gudelære, 1771, pp. 18-23. Han anforer, at han benytter den engelske udgave fra ${ }_{1} 765$.

(11) Kjobenhavnske lerde Efterretninger, 1792, pp. 404 ff. - (12) Iris, 1792, IV, pp. 214 f. - (13) Iris og Hebe, 1797, III, p. I6I. - (14) Se: Carl Roos: Øhlenschlæger og Ossian. Til Forklaring af et sted i Guldhornene, i: Danske Studier, 195I, pp. 7 I ff. og samme: Øhlenschlæger og Ossian. Et Supplement, ibid. 1952, pp. 127 ff. Mynsters brev til Ø.: Kgl. Bibl. NkS. I674, fol., I I I. - Mynster uddyber episoden i „Lidt Mere om Ossians Digte“, 1878 , hvor han skriver: „... men hele Svaret viste dog aldeles tydeligt, at han egentlig kun kjendte "Selmas Sange“ og nok ellers kun havde last hist og her $\mathrm{i}$ de andre Digte uden Sammenhang og at han altsaa her ikke havde den til en virkelig Kritik nødvendige Sagkundskab“. - (15) Blichers Erindringer, udg. af Søren Vasegaard, 1923 , p. V. - (16) Europaiske Ossian-illustrationer behandles i Henry Okun: Ossian in Painting, Journal of the Warburg \& Courtauld Institutes, XXX, London 1967 , pp. 327 ff. De franske Ossian-malerier behandles i Daniel Ternois: Ossian et les peintres, i: Colloque Ingres, Montauban 1969 , pp. $165 \mathrm{ff}$. der dog i det vasentlige er en gentagelse af Okuns artikel. - (17) Oskar Ulrich: Eine bisher unbekannte Radierung Goethes, Zeitschr. f. Bücherfreunde, II, 1907, pp. 283-86.

(18) Varker med Ossian-motiver, udstillet på Charlottenborg, efter de trykte kataloger: Salonen 1794, kat. nr. 31: Abildgaard: Culmins Gienfard viser sig for hans Moder, da hun endnu ikke havde Efterretning om hans Dod. Nr. 16o: Clemens: Ossian, efter Abildgaard. Udstillingen 1807, kat. nr. I I : L. C. Bryde: Digteren Ossian, malet i Oliefarve. 1810 , kat. nr. 16 : Eckersberg: Lorma finder hendes Elsker Aldo. 1811 , C.F.Høyer, kat. nr. 2: Cathmor. Kat. nr. 3: Sulmalla. Kat. nr. 4: Minvana. Minvana beklager Rynos Dod. Kat. nr. 27 : A.F. Wolffhecker: Digteren Ossian, efter Abildgaard. 1815, C. F. Høyer: kat. nr. 102: Luftens Son, eller Solen gaaer til Hvile. Kat. nr. 103: 
Lorma lyttende venter Aldo. Hun vidste ikke at han var falden. 1823, kat. nr. I3 $_{3}$ Hans Hansen: Copie af Stubs Malvinas Aand ved Ossian. Kat. nr. 23: C.F.Hoyer: Bosmina, Fingals Datter, kommer til Soras Fyrste for at magle Fred. Kat. nr. $7^{2}$ : C. Goos: Af Selmas Sang hos Ossian: Oldingen Arnim skuende sine 2de Borns Aander. 1824, kat. nr. 179: J. E. C.Walter: Cathmor som vaagner af en Drom i det hans Elskede, Sulmalla, varsler om en forestaaende Krig med Fingal; Efter Ossians Digt Temora $7 \mathrm{de}$ Sang. Stukket i Kobber efter et Malerie af Abildgaard. 1825 , kat. nr. 50 : A. Küchler: Ossian tilbyder Ninathoma, at bringe hende i sin Snekke til Berrathon. 1826 , kat. nr. 65: M. Rørbye: Oscar, hørende paa Ryno's Sang om Hidallan og Comalla. 1827, tillag til katalog, nr. 189 : C.Goos: Duschamor og Morna, efter Ossian. 1828, tillæg til katalog, nr. 190: F.L.Storck; Oscars Dod, efter Ossian. 1831, kat. nr. 81 : A.A.Müller: Ossian ledet over en Hede af Malvina.

(19) Om Abildgaards bibliotek se min artikel i Fund og Forskning, XVII, 1970, pp. 95 ff. Listen over bøgerne i Kgl. Bibl. NkS. 2337 , fol. - (20) Ossian i sin hule, se: Kat. over auktion nr. 261, Arne Bruun Rasmussen, marts 1971. - (21) Bente Skovgaard identificerer i „Maleren Abildgaard“, r961, scenen med det maleri, Abildgaard udstillede på Salonen i 1794 : „Culmins Gienfard . . .", men en sammenligning med tegningen i Kobberstiksamlingen med samme sujet synes ikke at godtgore, at Stockholmsbilledet gengiver denne episode. Den for Abildgaard să betydningsfulde nøjagtige gengivelse af tekstens ordlyd synes heller ikke iagttaget. Aldos genfærd som viser sig for hans elskede Lorma, beskrives derimod i en med billedet overensstemmende form: „His thin ghost appeared, on a rock, like a watery beam of feeble light: when the moon rushes sudden from between two clouds." - (22) Stikket: Leo Swane: J.F.Clemens, 1929, fort. nr. 245. Bluncks maleri på Statens Museum for Kunst, Marstrands i Det nationalhistoriske Museum på Frederiksborg.

(23) Otto v. Lutterotti: Joseph Anton Koch. 1768-1839. Berlin 1940. - (24) Om Napoleons Ossian-enthousiasme, der også bragte navnet Oscar ind i det svenske kongehus, se: van Tieghem, Ossian en France, II, I9I 7, pp. 3 ff. A.V. Arnault refererer i Souvenirs d'un sexagénaire, IV, I833, pp. $85 \mathrm{ff}$. en episode hvor Napoleon af bryder oplesningen af Odysseen og selv giver sig til at recitere Ossian. „Ces pensées, ces sentiments, ces images, disait-il, sont bien autrement nobles que les rabachâges de votre Odyssée. Voilà du grand, du sentimental, et du sublime. Ossian est un poète, Homère n'est qu'un radoteur.“ - (25) „Om Krazenstein Stub og hans efterladte Konstvarker", Athene, VIII, 1817, pp. 277. Tegningen var udstillet i 1816; se Catalog over de af Kratzenstein Stub udforte Malerier og Haandtegninger udstillede til Skue store Kjøbmagergade No. 6. 1816. - (26) Maleriet med samme motiv i Den Hirschsprungske Samling, kat. nr. I95, forekommer mig ikke helt overbevisende som et egenhandigt arbejde af Stub.

(27) Athene, VII, 1816, p. 148. - (28) Kgl. Bibl. NkS. 2337, fol. - (29) Peder Malling samlede mange af indlæggene $\mathrm{i}$ striden om universitetsudsmykningen, hvori koncepten til fru Abildgaards henvendelse findes foruden mange andre kuriøse bidrag. Samlingen overgået fra Kgl. Bibl. til Rigsarkivet. - På Kunstindustrimuseet findes tre nydelige skitser af Hoyer til udsmykningen, men ingen af dem synes at have ossiansk sujet. - (30) Haavard Rostrup: H.W.Bissen, 1945, fort. nr. 20: Ossian med 
Malvina og Alpin. Fort. nr. 82 b: Statuette af Ossian (?), omkr. 1835. Küchlers brev: Kgl. Bibl. NkS. 3341, $4^{\circ}$. - (31) Kgl. Bibl. Nyere Brevsamling D XI, brev fra Ditlev Martens til J.L.Lund, 15. august 1826: „Hansen (Historiemaler) er hatte auf der letzten Ausstellung aus Ossian das selbe welches Kratze(n)stein früher behandelt hat." (32) Kgl. Bibl. NkS. $3627,4^{\circ}$. I Emil Hannovers katalog i „Maleren Constantin Hansen", 1901, navnes to billeder fra denne periode: nr. 31, 1827 (?) En Tvekamp. Scene af Ossian. Nr. 32, 1827 (?) En Konge sidder sorgende ved sin Sons Grav og med en Hund ved sin Side. 